Snizhana A. Zagorodnya ${ }^{1}$, Ph. D., Senior Research Associate ORCID ID: 0000-0002-4332-4211e-mail: zagorodnya.s@gmail.com

Natalia A. Novokhatska ${ }^{1}$, Ph. D., Senior Research Associate ORCID ID: 0000-0002-5984-5580 e-mail: novokhatska.natalia@gmail.com

Viacheslav O. Okhariev ${ }^{1}$, Ph. D., Senior Research Associate ORCID ID: 0000-0001-6270-6293 e-mail: okhariev.vo@gmail.com

Maryna A. Popova ${ }^{1}, \mathrm{PhD}$, Senior Research Associate of the Ontological Systems and Applied Algebraic Combinatorics Department ORCID ID: 0000-0002-0258-1713 e-mail:pma1701@gmail.com

Igor V. Radchuk ${ }^{1}, \mathrm{Ph}$. D., Senior Research Associate ORCID ID: 0000-0003-4999-1258 e-mail: igor.radchuk.v@gmail.com

Taras V. Trysnyuk ${ }^{1}$, Ph. D., Junior Research Associate ORCID ID: 0000-0002-3672-8242 e-mail: trysnyuk@ukr.net

Viktor O. Shumeiko², Ph. D, Lecturer

ORCID ID: 0000-0002-0285-4566 e-mail: shym1983@ukr.net

Oleksandr V. Atrasevych ${ }^{1}$, Postgraduate student

ORCID ID: 0000-0001-7703-8494 e-mail: atras@ukr.net

${ }^{1}$ Institute of Telecommunication and Global Information Space of NASU, Kyiv, Ukraine ${ }^{2}$ Institute of Information Technologies of the National University of Defense of Ukraine, Kyiv, Ukraine

\title{
GIS-BASED ASSESSMENT OF ANTHROPOGENIC INFLUENCE IN WESTERN POLISSYA REGION LIMNOLOGICAL ECOSYSTEMS
}

\begin{abstract}
Results of expeditionary researches of limnological systems in Western Polissya region of hydroacoustic methods complex using and informationanalytical technologies are presented. Remote sensing monitoring method for lakes eutrophication processes research is considered. The concept of lake passport information model is proposed.

Keywords: environmental safety; influence assessment; limnological systems; eutrophication; environmental monitoring; Earth remote sensing methods; geographical information systems.
\end{abstract}

\section{Theme importance}

The problem of environmental conditions, water resources restoration and delivering high quality drinking water to consumers is one of the key problems not only in environmental sphere but one of the most important problems for humankind. This supposition confirms by assessment of qualified expert groups from different countries all over the world and international organizations. For example, among the

(C) S.A. Zagorodnya, N.A. Novokhatska, V.O. Okhariev, M.A. Popova, I.V. Radchuk, T.V. Trysnyuk, V.O. Shumeiko, O.V. Atrasevych, 2018 
latter, the analytical report of World Economic Forum experts "The Global Risk Report 2018"can be cited. In this assessment, the risk of "water crisis" is in the $5^{\text {th }}$ place in the global risks impact rating. Also, the water resources condition indirectly affects the other specific influential risk: "mankind unpreparedness to climate change" ( $4^{\text {th }}$ place), "natural disasters" ( $3^{\text {rd }}$ place), "extreme weather conditions" ( $2^{\text {nd }}$ place by influence and $1^{\text {st }}$ - by probability of occurrence risk). Surely, for Ukrainian territory the named risks are also relevant.

When speaking about solving the issues around water supply, water quality and water resources protection, the Ukrainian society and government regulates the above in a number of bylaws and international agreements, particularly, the Law "About main principles (strategy) of the state environmental policy in Ukraine for the period to 2020". There are agreements that are also dedicated to environmental policy transformation in accordance with sustainable development foundation. Problems of water resources monitoring, water quality control in natural reservoirs and hydro ecosystems sustainable functioning ensuring are in this list. Researching the limnological systems, i.e. lakes, water reservoirs, ponds are the part of these tasks. Its importance is linked to the increased requirements for the efficiency and information completeness during monitoring. The latter is carried out both by contact and remote sensing methods [1, 2]. However, current development level of infrastructure and information technologies enables to increase effectivity of these both methods combination. Contact methods allow to research physical, chemical, biological parameters simultaneously [3]. The remote sensing not only obtains geographic binding, but also water level dynamics monitoring, water area 3D-model creating, anthropogenic influence on coastal areas to water conditions assessment.

Fulfillment of the listed tasks with modern information technologies will allow to estimate anthropogenic impact peculiarities with more precision. In turn, it can lead to a refinement of the environmental assessment. Results can be used in water resources and environmental safety operation procedures.

The purpose of the research is to create and to improve information technologies for its usage in environmental safety management of limnological objects (lake ecosystems) of Ukraine as strategic sources of fresh water.

\section{Main content of research}

In the paper, authors considered the problem of monitoring efficiency increasing and assessment of limnological ecosystems ecological conditions on the example of Ukrainian lakes through creating and implementation of modern information technologies for further usage of the results in the system of territorial environmental management. Domestic and foreign research analysis show that the problem of hydro ecosystems conservation and restoration can be solved using geographic information system (GIS-based) technologies, remote sensing, integrated monitoring of ecosystems based on ecological indicators, databases with complex and local monitoring results, analytical technologies for remote sensing results processing and landfill and gauge measurements [4]. Authors made conclusion about expeditions of contact and remote limnological objects monitoring methods integration in order to solve named task.

After the analysis of Ukrainian limnological ecosystems, authors concentrated researches on a number of lakes located mainly in Western Polissya region. Lakes 
as Svityaz, Nobel, Lyubyaz, Bile and a number of smaller water objects [5, 6]. In the period since 2010 to 2017 , numbers of expeditions were carried out for every water object from the list. Expeditions consisted of the field research stage, when contact methods of lakes environmental monitoring and remote sensing data processing and analysis were used.

In the course of expeditions, a number of hydrochemical and hydrobiological measurements were performed, notably for Nobel and Lyubyaz lakes. In particular, transparency, salt content, $\mathrm{pH}$ parameters have got, samples of bottom sediments were taken using specialized developed equipment (geological tube). The results of field research made it possible to draw conclusions about the peculiarities of anthropogenic influence to these limnological ecosystems. In particular, intensive eutrophication of lakes' surface was observed due to changes in water chemical composition. It is being caused by mineral fertilizers flushing from agricultural lands and the active increasing of uncontrolled tourism and recreation scale [7]. Also, the water regime of the lakes gradually changes, in particular under the influence of climate factors. The anthropogenic disturbance level on these ecosystems is currently low, but there is continuous intensification of economic and recreational impact, that begins to influence on limnological objects negatively as a whole.

The authors propose the following algorithm to research anthropogenic influence in limnological systems using remote sensing methods:

- Selection of remote sensing data, cartographic materials and descriptive information;

- Creation of lake water area and coasts detailed digital map using ultra-high resolution remote sensing data;

- Determination of seasonal variability of the lake using time-varying images;

- Conducting the classification of the coastal territory to determinate coastal vegetation and anthropogenic impact on water object;

- Sources of anthropogenic influence determination;

- Classification of aquatic vegetation;

- Lake temperature regime determination using time-sensitive images in thermal channel;

- Measurements on the ground and water surface, test areas selection;

- Comparison and calibration of the results using remote sensing data processing and above-ground measurements;

- Limnological system geodatabase creating.

In order to increase the monitoring efficiency using remote sensing data, base of space images was created. It made it possible to research the dynamics of the environmental parameters. Limnological systems of Nobel lake (Rivne region), Lyubyaz (Volyn region, Pripyat - Stohid Natural Park) were considered as an example of the integrated application of remote sensing possibilities [6]. Highresolution images such as Spot, GeoEye, DigitalGlobe, Sich-2 with various ranges were used to analyze man-caused impact on the water areas of listed lakes and their coastal zones. Selection of remote sensing data, cartographic materials and descriptive information has been performed.

The analysis of eutrophication effect using space images processing methods is based on diffuse reflection coefficient of light by surface and subsurface water layers variation analysis. Coefficient changes when concentration of phytoplankton increases which in turn causes a diffuse reflection of light due to increased light 
scattering back to microalgae [8]. On the other hand, this process is accompanied by phytoplankton pigments content increasing that absorb light in specific intervals intensively. This process leads to a decrease in diffuse reflection of light in certain areas of the spectrum. It should be taken into account during remote monitoring for different periods of year.

For absorption processes, skin-effect impact is considered. It leads to decrease in the electromagnetic waves depth penetration into the thickness of conductive environment. Based on the Maxwell equations and the expression for electric power density vector, according to the Ohm law in differential form ( $j=\sigma E, E-$ vector of electric field strength; $\mu$ - magnetic permeability; $\sigma$ - specific electrical conductivity; $\mathrm{j}$ - electric current density vector; $\omega$ - frequency of electromagnetic wave), the basic model and $\Delta$ - thickness of the skin layer (absorption layer) $\Delta=\sqrt{2 / \sigma \mu \omega}$. It determines the effectiveness of light depth penetration in the conducted environment (in the case of water) for a given wavelength (frequency), which was chosen as $430-450 \mathrm{~nm}$. If the absorption of light effect and processes of its scattering and reflection is considered simultaneously, we can establish the total effect accuracy and determine the optimal wavelength, which was confirmed experimentally. As a result, we can confirm that there are three independent effects (reflection, scattering and absorption) which affect on the lake bottom image quality (depending on its depth).

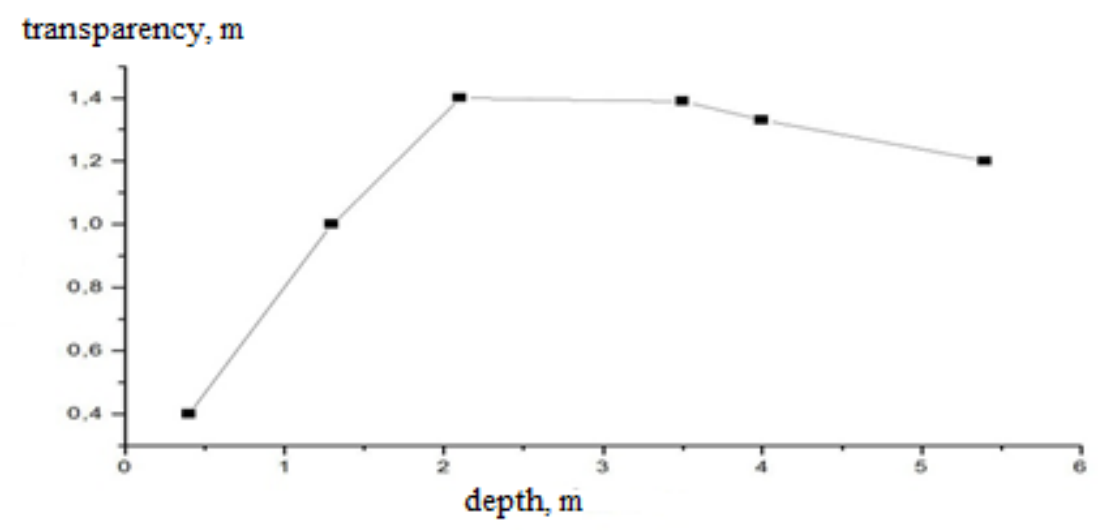

Fig. 1 - Dependence of transparency from depth (research of Nobel Lake)

The obtained data at one point for different depths (fig. 1) allowed constructing a functional dependence on the received light flux. Deducting of this dependence offers an opportunity to determine the influence of each of the three effects for a particular limnological object for each period of the year. That is why we can determine the content of suspended particles, presence and thickness of the water film the accuracy of depth remote measurement. It has been established that fixing continuous data for depth from 0 to $10 \mathrm{~m}$ provides the opportunity to obtain the most accurate result of measurement.

Equipment with available blue coastal canal $(0,40-0,45$ microns $)$ was used for limnological objects monitoring. Today there are only three satellites have such equipment on board - Landsat-8, WorldView-2, WorldView-3. Canal choice was due 
to penetration of sunlight in this spectral range at a greater depth. It allowed analyzing the spectral brightness of the main classes of natural objects in Nobel Lake basin.

\section{LAI - Leaf area Index}
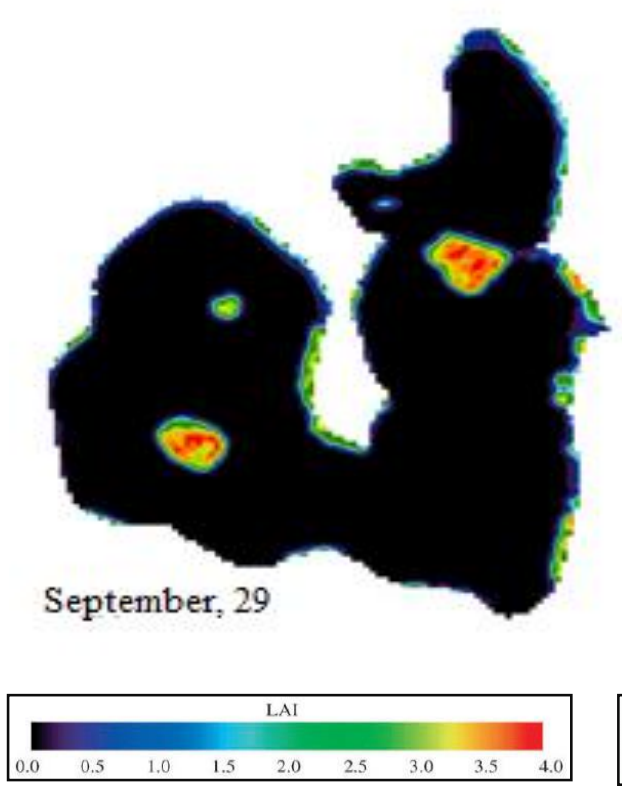

NDVI Normalized difference vegetation index
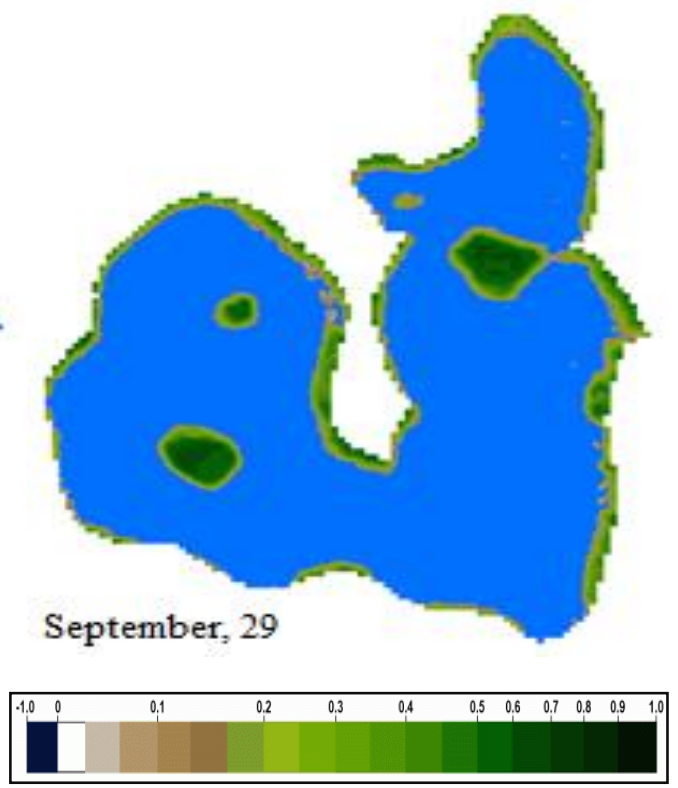

Fig. 2 - Classification of aquatic vegetation on Nobel Lake using LAI and NDVI indexes

The main periods of limnological objects seasonal variability were identified as a result of time-dependent remote sensing data analysis (fig. 2). In particular, it was discovered that in the warm period of the year there is an active reproduction of phytoplankton and algae in most lakes. During the cold season, water has maximum transparency and algae are falling to the bottom. Therefore, for aquatic vegetation monitoring, remote sensing data should be used for the summer period (July August). The depth definition measurement needs images for October and November. As a result, detailed digital map of water basin and coastal area was made using ultra-high spatial resolution space images.

Also, during the expeditions, hydroacoustic bathymetry of the water areas was conducted. On the measurement results, interactive maps of the bottom relief were constructed, as well as 3D-modeling of underwater relief. Fig. 3 shows one of the created lake bathymetry maps, for Lyubyaz Lake (Pripyat - Stohid Natural Park). The lake refers to flood-plain-channel way type, has irregular shape, the surface area is 519 hectares, the average depth is 5 meters. The coastline of the lake is low, sandy, mostly waterlogged, with an island.

In addition to direct depth measurements during expedition the echolocation method based on remote sensing was used on Nobel Lake [8, 9]. Results proved that using "WorldView-2" satellite images deliver more detailed bathymetry results (fig. 4).

Relative depths transformation into absolute values was carried out using reference points, which were selected using echolocation equipment. It allowed us to obtain data for constructing a depth map and a three-dimensional model of Nobel Lake. 


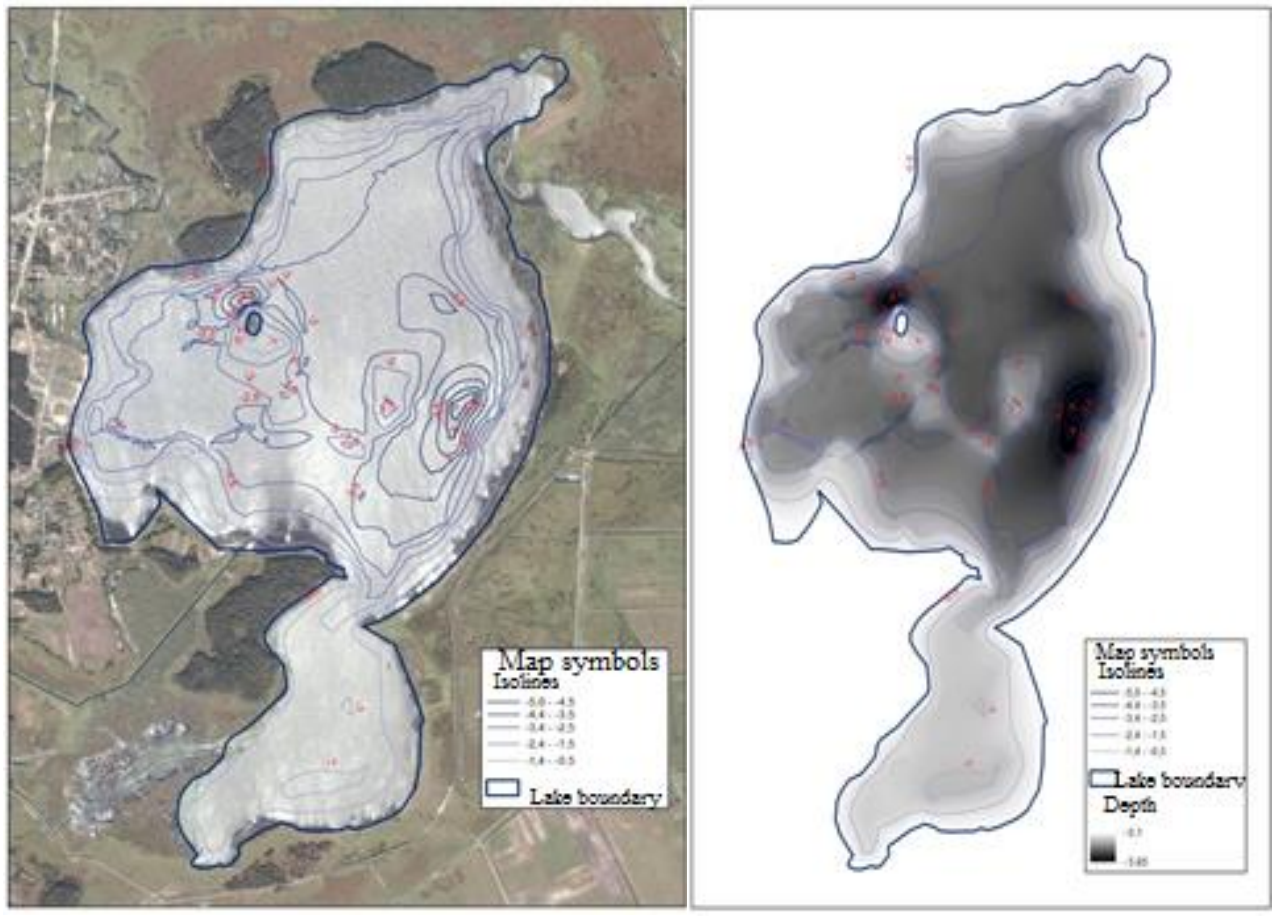

Fig 3 - Bathymetric map of Lyubyaz Lake limnological system (Pripyat - Stohid Natural Park)
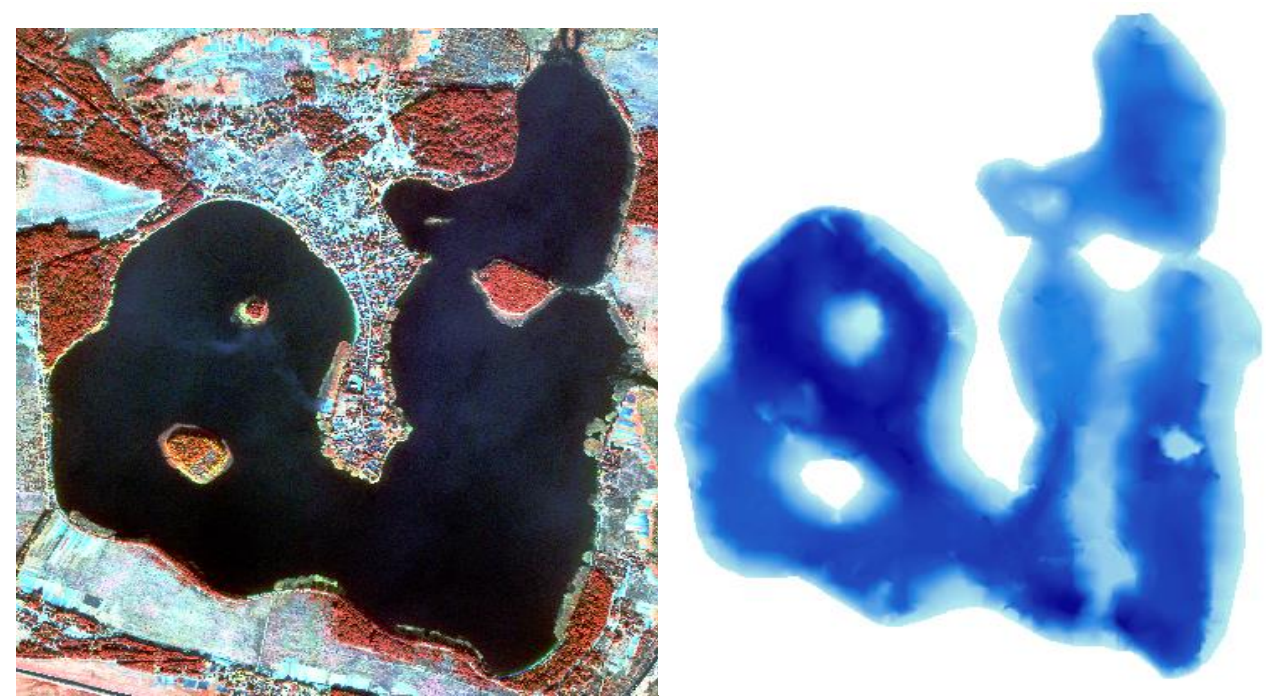

Fig. 4 - Nobel Lake satellite image (WorldView-2 remote sensing data) and bathymetric map based on result of its decoding

The results of experiments, measurements and remote sensing data allow to systematize individual parameters and to offer information technology for classifying the limnological object conditions in the form of passport $[8,10]$. For passport creating, methods for determine lake and coastal territories hydrochemical characteristics, satellite image processing, sub-satellite experiments, statistical 
analysis and processing physical, chemical, electrolytic, physicochemical, biological researches, spatial data GIS-processing were used. Basis for the passport creating is the ground binding of processed satellite images optical-spectral characteristics to the water area hydroecological conditions and landscape conditions of the limnological ecosystem territory.

Based on the ontology method, data package, collected during expeditions, the MS Excel toolbox (primary data spreadsheets) the lake passport information model was created. Also the query constructing rules were defined for forming user interface. These rules are essential for working with passport of limnological object through web-interface. Passport databases are implemented in Oracle environment. Passport technology proposes a sequential algorithm using to find information based on ontology method [11]. This method allows to obtain the exact information quickly, that is necessary for different groups of users. Ontology concept used to create limnological object passport has allowed reflecting the semantic properties of the research environment information resources logically.

The logical structure of lake e-passport shows object features and taking into account using requirements. Semantically, limnological object passport structure is represented in the scheme shown on Fig. 5.

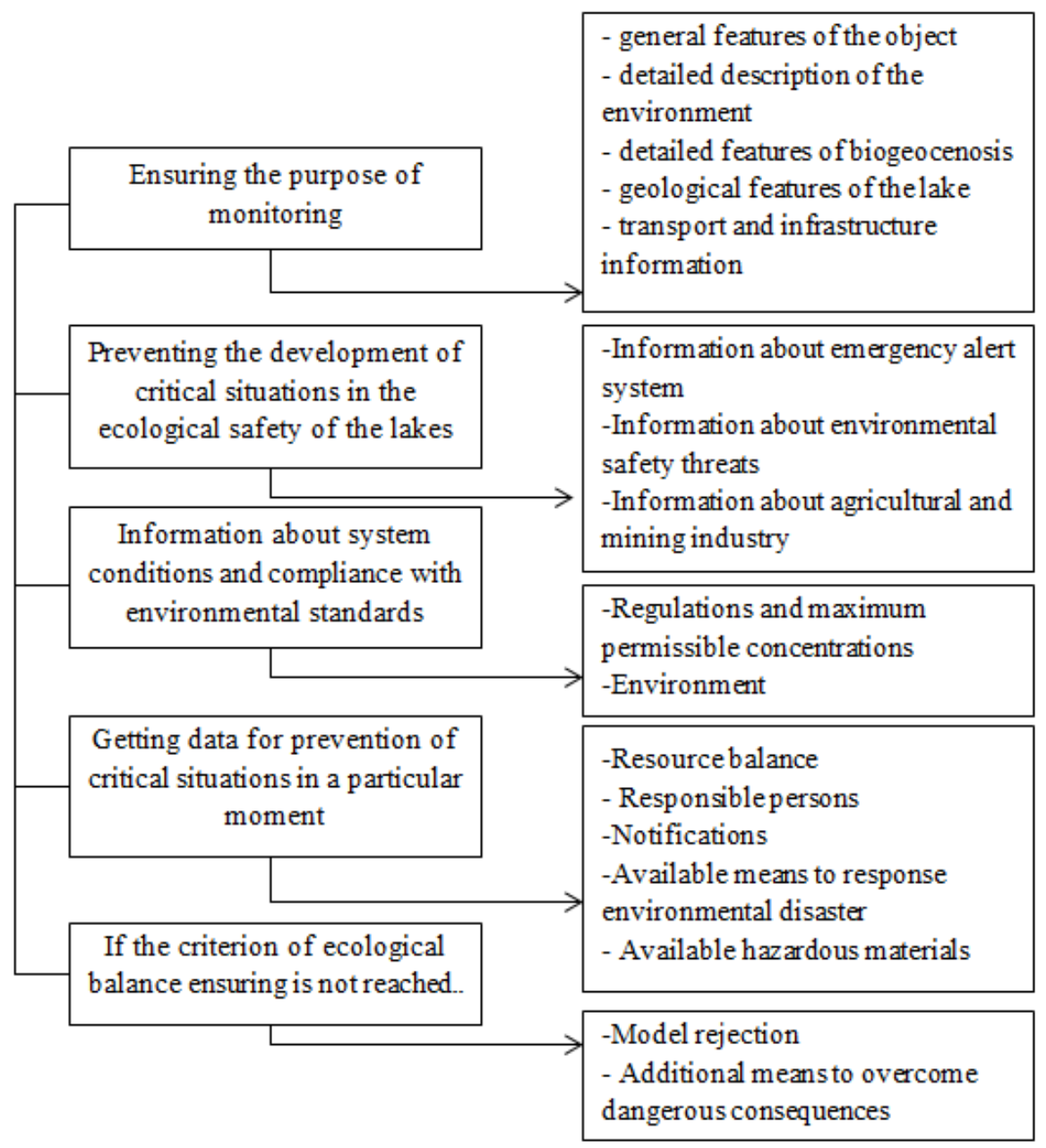

Fig. 5 - The structure of limnological object passport 
This scheme is based on mathematical models and satellite images processing results. It gives an idea of what questions this information model can answer of a particular limnological object in general. Also passport data should provide data for forecasting, that is, mathematical model creation. It allows the specialists in different areas to coordinate their efforts quickly and to take steps for environmental conditions stabilization.

After the passport was developed, the effectiveness parameter of user speed in the search of words in passport was determined. User interface of limnological object passport is preferable even for users with limited training. The average time of the operation of entering a search word to the search query in the system is $16,1 \mathrm{~s}$. Recommendations for implementation of limnological object passports indicate that the focus should be on natural reserves and natural parks.

\section{Conclusions and practical significance of the research result}

Authors proposed, grounded and applied the integration of ground-based monitoring for limnological ecosystems with space monitoring of water areas. Water regime of lakes in Western Polissya region was analyzed using presented methods. An increasing tendency of eutrophication effect has been established in Nobel Lake ecosystem. New technique to research absorption and dispersion effects was proposed and grounded mathematically. The methods, modern devices and software for bathymetric mapping of lakes were used. Method of hydroacoustic analysis of bottom lake relief for morpholithogenetic analysis of lake basins with different origins has been worked out, bathymetric mapping has been carried out. E-passport of the Nobel lake has been developed, a list of biotesting methods was presented with defined logical structure. Based on the collected data package, lake passport information model was created with the use of ontology method. The query constructing rules were defined for forming user interface. The passport implements the use of sequential algorithm to find information.

The practical significance of the results consists of satellite information base creation for the ecological monitoring in Western Polissya region. It allows to control the situation in water ecosystems, to analyze anthropogenic load on limnological objects. Technologies of environmental condition assessing for limnological ecosystems based on satellite information decoding methods (for freshwater reservoirs) was developed. Lake e-passport information technology was created. It allows to carry out situational environmental management depending on the intensity of anthropogenic influence.

\section{REFERENCES (TRANSLATED AND TRANSLITERATED)}

1. Informatyzacija aerokosmichnogo zemleznavstva / V.Y. Ljal'ko, S.O. Dovgyj, O.M. Trofymchuk [ta in.]; NAN Ukrai'ny, In-t geol. nauk, Centr aerokosm. doslidzhen' Zemli [ta in.]. - K. : Nauk. dumka, 2001. - 606 s. (in Ukrainian)

2. Remote sensing of the environment: an Earth resource perspective / J.R. Jensen. Prentice Hall, 2000. - 544 p. (in English)

3. Tehnoekologija: navch. posib. dlja stud. vyshh. navch. zakl. / V.M. Udod, V.V. Trofimovych, O.S. Voloshkina, O.M. Trofymchuk // KNUBA, In-t telekomunikacij i global'nogo informacijnogo prostoru NANU. - K., 2007. - 195 s. (in Ukrainian) 
4. Monitoryng navkolyshn'ogo seredovyshha $\mathrm{z}$ vykorystannjam kosmichnyh znimkiv suputnyka NOAA / [O.M. Trofymchuk, V.V. Radchuk, G.Ja. Krasovs'kyj, I.V. Radchuk] // Pid red. S.O. Dovgogo. - K., FOP Ponomarenko Je.V., 2013. - 316 s. (in Ukrainian)

5. Marynych O. Pro l'odovykovi ta vodno-l'odovykovi formy rel'jefu Ukrai'ns'kogo Polissja / O. Marynych // Nauk. zap. Kyi'v. derzh. un-tu. - 1958. - T. XVII. - Vyp. 1. - S. 115-121. (in Ukrainian)

6. Nacional'nyj park "Pryp'jat' - Stohid“ // Mizhderzhavni pryrodno-zapovidni terytorii' Ukrai'ny / Pid zag. redakcijeju d.b.n. T.L. Andrijenko, G.V. Parchuk, P.T. Jashhenko Mizhvidomcha kompleksna laboratorija naukovyh osnov zapovidnoi' spravy NAN Ukrai'ny ta Minekobezpeky Ukrai'ny. - K., 1998 . - S. 67-76. (in Ukrainian)

7. Rudenko V.P., Trofymchuk O.M. Ukrai'ns'kyj pryrodno-resursnyj potencial: Serija ocinkovyh kartoshem: Ch.2 // K., UINS, 2000. - 186 s. (in Ukrainian)

8. Information support of conception of environmental safety of water supply and wastewater treatment / [V.I. Mokryy, O.M. Trofimchuk, I.V. Radchuk, V.V. Radchuk, C.A. Zagorodnia, and other] // Water Supply and Wastewater Removal. - Politechnika Lubelska, edited by Henryk Sobczuk, Beata Kowalska. - Lublin. - 2016.- P. 132-145. (in English)

9. Informacijne zabezpechennja gidroakustychnogo monitoryngu ozer Zahidnogo Polissja / O.M. Trofymchuk, V.I. Mokryj, V.V. Radchuk, I.V. Radchuk, S.A. Zagorodnja // Ekologichna bezpeka ta pryrodokorystuvannja. - 2015. - № 17. - S. 5-14. (in Ukrainian)

10. Information Technology in Environmental Monitoring for Territorial System Ecological Assessment / [O. Trofymchuk, D. Kreta, M. Myrontsov, V. Okhariev, V. Shumeiko, S. Zagorodnia] // J. Environ. Sci. and Engineering. - 2015. - A4. - P. 79-84. (in English) 11. Stryzhak O.Je. Instrumenty informacijno-analitychnogo suprovodu procesiv monitoryngu / O.Je. Stryzhak // Ekologichna bezpeka ta pryrodokorystuvannja - K., 2014. Vyp. 14. - S. 180-191. (in Ukrainian)

\section{REFERENCES}

1. Інформатизація аерокосмічного землезнавства / В.И. Лялько, С.О. Довгий, О.М. Трофимчук [та ін.]; НАН України, Ін-т геол. наук, Центр аерокосм. досліджень Землі [та ін.]. - К. : Наук. думка, 2001. - 606 с.

2. Remote sensing of the environment: an Earth resource perspective / J.R. Jensen. Prentice Hall, 2000. - 544 p.

3. Техноекологія: навч. посіб. для студ. вищ. навч. закл. / В.М. Удод, В.В. Трофімович, О.С. Волошкіна, О.М. Трофимчук // КНУБА, Ін-т телекомунікацій і глобального інформаційного простору НАНУ. - К., 2007. - 195 с.

4. Моніторинг навколишнього середовища 3 використанням космічних знімків супутника NOAA / [О.М. Трофимчук, В.В. Радчук, Г.Я. Красовський, І.В. Радчук] // Під ред. С.О. Довгого. - К., ФОП Пономаренко С.В., 2013. - 316 с.

5. Маринич О. Про льодовикові та водно-льодовикові форми рельєфу Українського Полісся / О. Маринич // Наук. зап. Київ. держ. ун-ту. - 1958. - T. XVII. - Вип. 1. C. $115-121$.

6. Національний парк “Прип’ять - Стохід“ // Міждержавні природно-заповідні території України / Під заг. редакцією д.б.н. Т.Л. Андрієнко, Г.В. Парчук, П.Т. Ященко - Міжвідомча комплексна лабораторія наукових основ заповідної справи НАН України та Мінекобезпеки України. - К., 1998 . - С. 67-76.

7. Руденко В.П., Трофимчук О.М. Український природно-ресурсний потенціал: Серія оцінкових картосхем: Ч.2 // К., УІНС, 2000. - 186 с.

8. Information support of conception of environmental safety of water supply and wastewater treatment / [V.I. Mokryy, O.M. Trofimchuk, I.V. Radchuk, V.V. Radchuk, C.A. Zagorodnia, and other] // Water Supply and Wastewater Removal. - Politechnika Lubelska, edited by Henryk Sobczuk, Beata Kowalska. - Lublin. - 2016.- P. 132-145. 
9. Інформаційне забезпечення гідроакустичного моніторингу озер Західного Полісся / О.М. Трофимчук, В.I. Мокрий, В.В. Радчук, І.В. Радчук, С.А. Загородня // Екологічна безпека та природокористування. - 2015. - № 17. - С. 5-14.

10. Information Technology in Environmental Monitoring for Territorial System Ecological Assessment / [O. Trofymchuk, D. Kreta, M. Myrontsov, V. Okhariev, V. Shumeiko, S. Zagorodnia] // J. Environ. Sci. and Engineering. - 2015. - A4. - P. 79-84.

11. Стрижак O.С. Інструменти інформаційно-аналітичного супроводу процесів моніторингу / О.С. Стрижак // Екологічна безпека та природокористування - К., 2014. - Вип. 14. - С. 180-191.

Text of the article was accepted by Editorial Team 15.02.2018

С.А. Загородня, Н.А. Новохацька, В.О. Охарєв, М.А. Попова, І.В. Радчук, Т.В. Триснюк, В.О. Шумейко, О.В. Атрасевич

\section{ГІС-ОЦІНКА АНТРОПОГЕННОГО ВПЛИВУ В ЛІМНОЛОГІЧНИХ ЕКОСИСТЕМАХ ЗАХІДНОГО ПОЛІССЯ}

Анотація. Наведені результати експедиційних досліджень лімнологічних систем Західного Полісся на основі комплексного використання гідроакустичних методів та інформаційно-аналітичних технологій. Розглянуто методику дистанційного моніторингу евтрофікаційних процесів озер, запропонована концепція інформаційної моделі паспорту озера.

Ключові слова: екологічна безпека; оцінка впливу; лімнологічні системи; евтрофікація; екологічний моніторинг; дистанційні методи зондування Землі; геоінформаційні системи.

\section{Автори (науковий ступінь, вчене звання, посада):}

\section{Загородня Сніжана Анатоліївна}

кандидат технічних наук, старший науковий співробітник відділу досліджень навколишнього середовища

Інститут телекомунікацій і глобального інформаційного простору НАН України

Адреса робоча: 03186 Україна, м. Київ, Чоколівський бульвар, 13

ORCID ID: 0000-0002-4332-4211e-mail: zagorodnya.s@gmail.com

\section{Новохацька Наталя Анатоліївна}

кандидат технічних наук, старший науковий співробітник відділу досліджень навколишнього середовища

Інститут телекомунікацій і глобального інформаційного простору НАН України

Адреса робоча: 03186 Україна, м. Київ, Чоколівський бульвар, 13

ORCID ID: 0000-0002-5984-5580 e-mail: novokhatska.natalia@gmail.com

\section{Охарсв Вячеслав Олександрович}

кандидат технічних наук, старший науковий співробітник відділу природних ресурсів Інститут телекомунікацій і глобального інформаційного простору НАН України

Адреса робоча: 03186 Україна, м. Київ, Чоколівський бульвар, 13

ORCID ID: 0000-0001-6270-6293 e-mail: okhariev.vo@gmail.com

\section{Попова Марина Андріївна}

кандидат технічних наук, старший науковий співробітник відділу онтологічних систем та прикладної алгебраїчної комбінаторики

Інститут телекомунікацій і глобального інформаційного простору НАН України

Адреса робоча: 03186 Україна, м. Київ, Чоколівський бульвар, 13

ORCID ID: 0000-0002-0258-1713 e-mail: pma1701@gmail.com 


\section{Радчук Ігор Валентинович}

кандидат технічних наук, старший науковий співробітник відділу досліджень навколишнього середовища

Інститут телекомунікацій і глобального інформаційного простору НАН України

Адреса робоча: 03186 Україна, м. Київ, Чоколівський бульвар, 13

ORCID ID: 0000-0003-4999-1258 e-mail: igor.radchuk.v@gmail.com

\section{Триснюк Тарас Васильович}

кандидат технічних наук, молодший науковий співробітник відділу прикладної математики

Інститут телекомунікацій і глобального інформаційного простору НАН України

Адреса робоча: 03186 Україна, м. Київ, Чоколівський бульвар, 13

ORCID ID: 0000-0002-3672-8242 e-mail: trysnyuk@ukr.net

\section{Шумейко Віктор Олександрович}

кандидат технічних наук, викладач

Інститут інформаційних технологій Національного університету оборони України Адреса робоча: 03049 Україна, м. Київ, Повітрофлотський проспект, 28

ORCID ID: 0000-0002-0285-4566 e-mail: shym1983@ukr.net

\section{Атрасевич Олександр Валентинович}

аспірант

Інститут телекомунікацій і глобального інформаційного простору НАН України

Адреса робоча: 03186 Україна, м. Київ, Чоколівський бульвар, 13

ORCID ID: 0000-0001-7703-8494 e-mail: atras@ukr.net 